\author{
A. $\mathrm{Kim}^{1}$, D. Assanova ${ }^{2}, \mathrm{M} . \mathrm{Knol}^{2^{*}}$ \\ ${ }^{I}$ Tomsk State University, Russia \\ ${ }^{2}$ Karagandy university of the name of academician E.A. Buketov, Kazakhstan \\ (Corresponding author's E-mail: marina_vagner@mail.ru) \\ ORCID 0000-0002-4624-7012 2
}

\title{
The nature and content of psychological-pedagogical problems of multilingualism: linguistic and psychological aspects
}

\begin{abstract}
Recently the concept of multilingualism has become a defining approach to the problem of language learning. Multilingualism occurs as an individual's language experience, expands culturally from the language used in the family to the language used in society, and then to the acquisition of languages of other peoples. The individual does not "keep" these languages and cultures separate from each other, but forms a communicative competence based on all knowledge and all language experience, where languages are interconnected and interact with one another. One of the most important approaches to both bilingual and multilingual education is, in our opinion, the study of psycholinguistic and neuro-linguistic mechanisms of bilingualism and multilingualism formation. The peculiarity of the language situation of the Republic of Kazakhstan is the presence of bilingualism, which occured in the country as a natural process in a multinational state. However each region of the country has its own specifics in terms of language. In this regard, there is a need for a regional approach to the study of the language situation in the Republic of Kazakhstan. It is worth noting that the definition of the role and place of Russian language in teaching a foreign language in the context of multilingualism is insufficiently studied. Russian language is not only a universal means of communication generally accepted in the Republic of Kazakhstan, but also the main means of knowledge of sciences and support in learning a foreign language. Linguistic situation of foreign language teaching in multilingual environment in many respects differs from the linguistic situation of learning a foreign language in a monolingual audience.
\end{abstract}

Keywords: multilingualism, linguistic aspect, psychological aspect, language, foreign language, language situation, mutual understanding of languages, multilingualism, language culture.

\section{Introduction}

Multilingualism is understood in many studies as the ability of an individual or a whole nation (or part of it) to communicate in order to achieve mutual understanding by means of two or more languages.

Scientific, technical, and cultural progress helps to attract representatives of different peoples of the world to international life, which, in turn, requires society to find ways that would help achieve mutual understanding between representatives of different peoples. The best way out of this situation is to learn several languages that could meet the social needs of both the individual and the entire society. Under these conditions the problem of multilingualism, that is, knowledge of one's native language and other most common languages, has become particularly relevant.

The problem of multilingualism is multidimensional. The study intersects different approaches: psychological, linguistic, and social. Yu.D. Desheriev believes that this problem should be considered in the sociolinguistic aspect as "a product of language functioning in certain social conditions" [1].

When considering the concept of "multilingualism", it is necessary to take into account its types and varieties. Terms of multilingualism, the nature of the relationship of multilingualism with thinking, a way of reaffirming of the speech mechanisms with each other, the degree of difference between languages in contact, the kinship of languages are the most commonly studied aspects of multilinguali sm [2].

Multilingualism in the narrow sense implies more or less fluency in two or more languages: native (Kazakh), non-native (Russian), foreign (English); multilingualism in the broad sense is a relative command of a second or third language, the ability to use two or more languages in certain areas of communication.

\section{Experimental}

According to H.Z. Bagirokov, "bilingualism/polylinguism is the result of intercivilized interaction of different cultures of peoples, one of the forms of adaptation of a completely different or related language 
culture" [2]. Multilingualism is the practice of alternative use of two or more languages, which has emerged as a result of the interaction of different languages and cultures. V.A. Avrorin understands real bilingualism/polylinguism as "almost equal free active knowledge of two or more languages. Real bilingualism/polylinguism begins when the degree of proficiency in the second language approaches the degree of proficiency in the first" [3].

However, the degree of proficiency in a second or third language may vary. In accordance with the classificati on of T.A. Bartalev, bilingualism/multilinguali sm is divided into the following types:

1) normalized;

2) one-way normalized;

3) non-normalized.

The normalized type, according to the author, is characterized by compliance with the norms (grammatical, lexical-semantic, phonetic) of the studied languages. A one-sided normalized type is one in which the speaker adheres to the norm of one, usually native language. Non-normalized bilingualism/polylinguism is the use of a second language with a violation of its norm in part or in full [4].

Y.D. Desheriev identifies two types of bilingualism/polylinguism:

1) contact bilingualism/polylinguism: the result of the common residence of two or more peoples (the contact type of bilingualism is inherent in countries located in the former post-Soviet space);

2) non-contact bilingualism/polylinguism, when there is no contact between two peoples; language acquisition occurs through communication with representatives of people who live on the territory of another country, or by studying a forei gn language at school or university.

T.A. Bartalev allocates active and passive bilingualism/multilingualism. He offers a definition of active and passive bilingualism, considering active bilingualism/polylinguism as such bilingualism in which a person is fluent in a second language in all its forms. Passive bilingualism is a type of bilingualism in which a person partially speaks a second language: understands, but does not speak [4].

V.A. Itskovich and V.S. Schwarzkopf offer a broader definition of passive bilingualism. Passive bilingualism/polylinguism "refers to a type of bilingualism in which a native speaker reads fluently (to a greater or lesser extent) in a second language, but does not speak it" [5].

Multilingualism is characterized by varying degrees of proficiency in the first, second, and third languages. "Degree of proficiency in the second (third) language can be both high and low when a limited number of words and basic rules are learned, and when the ability to express fragmentary opinions of everyday content is obvious" [5].

With active bilingualism/polylinguism the native speaker is fluent in the second (third) language and uses it in everyday life. There is a distribution of communication functions between languages depending on the language environment. Passive bilingualism assumes that a native speaker is fluent in a second language, but does not use it due to the lack of an appropriate environment.

According to the degree of extensiveness, bilingualism/polylinguism is divided into the following types: national, territorial, and bilingualism of a certain stratum of society (classification by Yu.D. Desheriev). Each of these classifications requires detailed consideration. National bilingualism/polylinguism, as defined by Yu.D. Desheriev, concerns the people as a whole [1].

With regard to the two last mentioned varieties, they can only oppose the first in aggregate, since one and the second do not concern the whole people, but only one or another part of it: the first is territorial, the second is social.

Based on the classification of T.A. Bertogaev, indi vi dual bilingualism/polylingui sm is the property of individual native speakers, it is found in all peoples of the world.

Group bilingualism/polylinguism covers a compact group of the population: it can be, for example, socio-group (intelligentsia bilingualism). Bilingualism/polylingui sm of the main group of native speakers (with the exception of certain groups of adults and children of a certain age) of the population of a certain country belongs to the mass one [4].

Multilingualism is defined as the use of several languages within a certain social community; the use by an individual or group of people of several languages, each of which is chosen in accordance with a specific communicative situation [6].

There are two types of multilingualism: dominant, when one of the languages is the main, source; equal, when none of the languages is given an advantage. Define the following typical cases of formation of multilingualism: a) the child is brought up to "switch" from one language to another; b) child in the family 
speaks their native language, and it is possessed by other languages; c) the students learn second foreign language in the process of purposeful learning.

Multilingualism is closely related to the psychological aspects of communication. Knowledge of several languages contributes to the development of such mental functions as thinking, memory, imagination, perception.

According to E.M. Vereshchagin, in the psychological aspect bilingualism/polylinguism is characterized by its own specifics. Degree of proficiency in the second (third) the language is evaluated by the number of actions that are performed during the implementation of the communication. In accordance with the point of view of E.M. Vereshchagin, receptive bilingualism/polylingui sm allows a bilingual to understand the language structures inherent in the secondary language system, but no more; reproductive bilingualism/polylinguism allows a bilingual to reproduce what is read or heard; productive bilingualism/polylinguism allows not only to understand and reproduce the language formations inherent in the secondary language system, but also to create them [7].

B.V. Belyaev distinguishes two types of bilingualism/polylinguism: direct, when primary and secondary language skills are directly related to thinking; indirect, when a bilingual refers to a secondary language as a code system in order to indicate the capabilities of the primary language [1].

In the modern methodological literature a large number of works on the problems of teaching a foreign language in the national school can be found (R.Yu. Barsuk, G.M. Vishnevskaya, Yu.D. Desheriev, A.S. Markosyan, Z.G. Muratova, L.S. Khalatyan, A.I. Yatsikevichus, etc.).

Despite the general patterns of learning a foreign language in the context of multilingualism, each specific case requires individual consideration. Some authors study certain aspects of teaching a foreign language in a national audience, based only on the study of the native (national) language of students (Kh.Z. Bagirokov, L.M. Bayramova, A.E. Karlinsky, R.N. Kremer, etc.). Other authors emphasize the need to take into account the Russian language in the process of mastering a foreign language (I.O. Ilyasov, A.M. Mikhailov, L.V. Kobakhidze, V.F. Rumyantsev, N.N. Fomin, etc.). The analysis of research shows that learning Russian contributes to mastering the third and fourth languages, i.e., in conditions of bilingualism or polylinguism, there is a psychological readiness to learn subsequent languages (B.V. Belyaev, I.A. Zimnyaya). It should be concluded that the knowledge of the native language and Russian in the national school significantly facilitates the process of learning a foreign language.

Despite the fact that the native language (Kazakh) in the territory of the Republic of Kazakhstan prevails in public life, in cultural outreach, in live communication, it is used in the education system, in the media, Russian continues to be a means of broad international communication throughout the territory of the Republic of Kazakhstan, the language of education and science.

The multilingual environment in which the younger generation of the Republic of Kazakhstan grows and communicates becomes a favorable ground for learning a foreign language (in this case, English).

The problem of multilingualism is considered in modern research from different perspectives. This problem is considered from the linguistic point of view in the research of such scientists as V.D. Arakin, Zh.L. Vitlin, R.N. Kremer, L.N. Kovylina, I.I. Khaleeva, and L.V. Shcherba. From a psychological point of view this problem is presented in the research of V.B. Belyaev, Z.U. Blyagos, L.S. Vygotsky, L.B. Itelson, and others. Sociocultural aspects of the problem of multilingualism are reflected in the research of Y.L. Vorotnikov, M.N. Guboglo, V.V. Safonova, P.V. Sysoev, and S.G. Ter-Minasova. Methodological aspects of the study of multilingualism were studied by I.L. Bim, N.D. Galskova, P.B. Gurvich, B.A. Lapidus, R.P. Milrud, E.I. Passov, and others.

The peculiarity of the modern language situation in the Republic of Kazakhstan also implies the need to address the concept of "dominant language" as one of the key sociolinguistic concepts used in the course of the study. The dominant language is most often the language of interethnic communication.

As U. Weinreich points out, "the psychological dominance of one language over another can be established by tests of varying degrees of complexity. One might wonder, for example, which of the two languages is the more convenient means of communicating orders that must be executed quickly and accurately. It is even possible to pose the question: in what language does a bilingual speaker "think"; to do this, you need to check in which language he is more willing to give associations to stimuli presented to him at random in both languages. On the other hand, one can hold the view that the "dominance" of language is a complex combination of factors of approximately the following type. By comparative language proficiency, the dominant language is the one that the native speaker has a better command of at a given time in their life. According to the method of use, visual reactions are so important for strengthening the oral use of a language 
that for a bilingual native speaker who is literate in only one of the languages, this language will be the main one, regardless of the ratio in the level of oral proficiency in these languages". In this work, which has become a classic for the typology of bi- and polylinguism, we also present the provisions that have not lost their relevance on the allocation of the dominant language by the order of study and age, by the role in communication. Weinreich emphasizes that while a bilingual speaker may be equally proficient in both languages, it may be that they are more likely to have to resort to one rather than the other; at the same time, more frequent use of the language can, all other things being equal, raise it to the rank of "dominant" language, which often took place in the situation of Kazakh-Russian bilingualism, as well as the following principle of typologization - the dominance of the language, depending on its role in the social promotion of the speaker). In the cited work W. Weinreich also notes the pronounced need to overcome the potential interference in the latter case, which is especially important for the study we have undertaken. [8]

\section{Results and Discussion}

Multilingualism is a common linguistic phenomenon that has been observed at different times among different peoples of the world. Multilingualism occurs where there are close socio-economic ties between members of different ethnic groups who speak different languages. The phenomenon of multilingualism is inherent in multinational countries.

The study of multilingualism is related to the study of bilingualism. It should be noted that there are different interpretations of the content of the concept of "bilingualism".

V.A. Avrorin notes that "bilingualism occurs when the team, in addition to the native language, has another language that can perform the same functions as the native language. Most often, these functions are distributed between languages, but it is important that they are both able to perform the same functions in a certain team, and this is possible if there is no significant difference in the degree of proficiency and activity of using both languages. Therefore, bilingualism begins when the degree of proficiency in the second language is as close as possible to the degree of proficiency in the first" [5].

Investigating the problem of bilingualism, V.A. Itskovich and V.S. Schwarzkopf note that bilingualism is "usually an active possession of two language systems. However, in modern society, with a mass desire to master a second language (or languages) and the active spread of foreign-language literature, there is a situation when the second language, with bilingualism, does not perform all its functions" [8].

Under the nature of the relationship between languages, L.V. Shcherba distingui shes between pure and mixed bilingualism/polylinguism. The scientist considered pure bilingualism to be the case when in the mind of a native speaker two languages exist in isolation from each other, without any comparisons and parallels. This is confirmed by the Russian aristocrats, who were fluent in Russian and French, but translation from one language to another was difficult. Such bilingualism occurs as a result of mastering languages in the so-called "natural" way, when the second language is studied in isolation from the first [9].

Mixed bilingualism/polylinguism allows parallel communication of equivalent means of two or more languages with their corresponding concepts, and through them between the languages themselves. According to L.V. Shcherba, mixed bilingualism should be considered normal because pure bilingualism occurs only under special conditions [9].

The formation of bilingualism/polylinguism is a long process because the acquisition of a second language is gradual.

$\mathrm{Kh}$. Z. Bagirokov, investigating the problem of language acquisition in multinational republics, identified the following types of bilingualism/polylinguism:

- the first degree involves the possession of a second language, in which there is interference of the maximum type at all levels of forei gn (other) speech;

- the second degree involves proficiency in a second language, in which there is interference of the maximum type at the grammatical and lexical-semantic level and phonetic level;

- the third degree involves knowledge of a second language, in which there is interference only at the lexical and semantic level;

- the fourth degree involves the possession of a second language, in which there is minimal interference at all levels;

- the fifth degree involves the possession of a second language, in which there is minimal type of interference at the grammatical and lexical-grammatical level;

- the sixth degree involves the possession of a second language, in which there is minimal interference only at the lexicosemantic level; 
- the seventh degree involves the possession of a second language, in which there is only stylistic interference;

- the eighth degree implies second language proficiency, when an individual is proficient in literary and written language in all functional styles, without allowing any deviations.

- The linguistic aspect of the study of bilingualism and polylinguism is to analyze the relationship between the structures and structural elements of several languages, their mutual influence, interaction and interpenetration at different levels of languages, and to identify interference at different levels of language structure. Polylinguism is a great cultural asset. Its development is in no way an obstacle to the development of national languages, on the contrary, as an extralinguistic factor, it can be one of the important sources of subsequent development of national languages [10].

L.V. Shcherba distingui shes two types of coexistence of language systems in the consciousness of an individual with respect to bilingualism. For L.V. Shcherba under pure bilingualism we should understand parallel, but independent study of two languages. By mixed bilingualism, he means bilingualism formed as a result of the comparative study of two languages, when the second language is studied on the basis of the first [9].

According to the method of comparing two languages in the mind of a bilingual, V.Y. Rosenzweig distinguishes between coordinate bilingualism (a bilingual speaks both languages equally and switches from one to the other depending on the communi cation situation) and subordinate bilingualism (a bilingual is fluent in only one, native language, which subordinates another, non-native language in his mind) [11].

\section{Conclusions}

In the linguistic aspect multilingualism is defined, on the one hand, as perfect knowledge of the native and other languages studied, the use of two (three) languages as full-fledged, and, on the other hand, as the ability to use the second (third) language in certain areas of communication.

The problem of bilingualism/polylinguism in the psychological aspect is considered as a problem of proficiency in various language codes and as a problem of interaction of these codes. Mastering the second (third) language theoretically cannot be evaluated as a process of mastering a new system of thinking, but it is mastering a new code that is imposed on the code of the native language [12].

Significant attention is paid to the study of the influence of multilingualism on thinking and intellectual development of the child. L.S. Vygotsky concluded that the solution of this issue depends on the age of the child, the nature of the interaction of languages and, most importantly, on the pedagogical influence on the development of speech skills of the native and foreign languages.

The analysis of the process of interaction of languages is undoubtedly important when developing a methodology for teaching a foreign language to students in a multilingual environment.

Many authors believe that children in the context of bilingualism/multilingualism the interfering occurs resulting in the fusion of language systems.

At preschool age children are already able to understand the bilingualism that manifests itself:

1) in the general view of the presence of two different linguistic systems of Russian and foreign languages;

2) awareness of differences in the grammatical structure of the language, which is manifested in selfcorrection and in correcting errors in the speech of other children;

3 ) in the awareness of similar and different phonetic systems;

4) awareness of the synonymy of two words in different linguistic systems;

5) the word becomes an object of awareness [13].

The problem of multilingualism is relevant, since the current stage of human civilization development is impossible without the interaction of different languages and cultures.

The process of teaching a foreign language in a multilingual environment should be aimed at creating a single cognitive base for several languages used and studied. Students should be given the opportunity to follow the already developed strategy for mastering their native language (Kazakh) and Russian, as well as build a new strategy that is adequate to the process of mastering a foreign language (English). Taking into account known and new strategies for language acquisition in a multilingual environment allows for more effective interpretation and application of complex interactions between the native language (Kazakh), Russian, and a foreign language (English).

The process of learning a foreign language in a multilingual environment should be aimed at taking into account the different and shared features of the grammatical systems of the languages being studied, 
which will be the orientation basis for learning a foreign language and mastering the necessary cognitive base for learning English in terms of its interaction with the native language (Kazakh) and Russian.

Possession of a single cognitive base leads to the creation of a polylingual state of students, which allows for the transition from the lower stage of multilingualism to a higher one.

The process of learning a foreign language in a multilingual environment should be based on the laws of real communication.

\title{
References
}

1 Дешириев Ю.Д. Предисловие к сб. «Проблемы двуязычия и многоязычия»: учеб. пос. / Ю.Д. Дешириев. — М., 2006. $-16 \mathrm{c}$.

2 Аврорин В.А. Двуязычие и школа: тез. науч. конф., посвящ. проблеме двуязычия и многоязычия / В.А. Аврорин. M., 2018. - $5 \mathrm{c}$.

3 Беляев Б.В. Применение принципа сознательности в обучении иностранному языку. В сб. «Психология обучения иностранному языку»: учеб. пос. / Б.В. Беляев. — М., 2015. - 10 с.

4 Бертагаев Т.А. Билингвизм и его разновидности в системе употребления / Т.А. Бергагаев // Проблемы двуязычия и многоязычия: учеб. пос. - М., 2008. - 86 с.

5 Аврорин В.А. Двуязычие и школа. Проблемы двуязычия и многоязычия: учеб. пос. / А.В. Аврорин. — М.: Наука, 2010. $-58 \mathrm{c}$.

6 Верещагин Е.М. Психологическая и методическая характеристика двуязычия (билингвизма): учеб. пос. / Е.М. Верещагин. - М., 2016. - 158 с.

7 Мирзоева Л.Ю. К вопросу об интерферентных ошибках как элемент языкового ланшафта в условиях субординативного полиязычия / Л.Ю. Мирзоева, З.К. Ахметжанова // Вестн. Том. гос. ун-та. Филология. - 2019. - № 60. - C. 45-65. DOI: $10.17233 / 19986645 / 60 / 4$

8 Ицкович В.А. Пассивное двуязычие и культура родной речи // Проблемы двуязычия и многоязычия: учеб. пос. / В.А. Ицкович, В.С. Шварцкопф. - М., 2017. — 128 с.

9 Щерба Л.В. Избранные работы по языкознанию и фонетике: учеб. пос. / Л.В. Щерба. — Т. 1 - СПб., 2009. — 181 с.

10 Багироков Х.З. Билингвальное образование: вызов времени: учеб. пос. / Х.З. Багироков. - М., 2004. - 32 с.

11 Розенцвейг В.Ю. О языковых контактах как степени двуязычия / В.Ю. Розенцвейг // Вопросы языкознания: учеб. пос. - СПб., 2014. - 68 с.

12 Блох М.Я. Теоретическая грамматика английского языка: учеб. для студ. филол. фак. и фак. англ. яз. педвузов: учеб. пос. / Я.М. Блох. — М., 2017. — 275 с.

13 Тер-Минасова С.Г. Язык и межкультурная коммуникация: учеб. пос. / С.Г. Тер-Минасова. — М., 2004. — 40 с.

\author{
А. Ким, Д. Асанова, М. Кноль
}

\section{Көптілдіктің психологиялық-педагогикалық мәселесінің мәні мен мазмұны: лингвистикалық және психологиялық аспектілер}

Соңғы кездері көптілділік тұжырымдамасы тілдерді оқыту мәселесіне қатысты шешуші орында. Көптілділік адамның тілдік тәжірибесінің мәдени аспектісінде, отбасында қолданылатын тілден қоғамда қолданылатын тілге дейін, содан кейін басқа халықтардың тілдерін игеруге дейін кеңейді. Жеке тұлға бұл тілдер мен мәдениеттерді бір-бірінен бөлек «сақтамайды», бірақ тілдер өзара байланысты және өзара әрекеттесетін барлық білім мен барлық тілдік тәжірибе негізінде коммуникативті құзыреттілікті қалыптастырады. Билингвалды және көптілді білім берудің маңызды тәсілдерінің бірі, біздің пікірімізше, билингвизмді, көптілділікті қалыптастырудың психолингвистикалық, нейролингвистикалық механизмдерін зерттеу болып табылады. Қазақстан Республикасындағы тілдік ахуалдың ерекшелігі - көп ұлтты мемлекеттегі табиғи процесс ретінде елде негізделген екі тілділіктің болуы. Алайда, елдің әр аймағының тілдік тұрғыдан өзіндік ерекшелігі бар. Осыған байланысты Қазақстан Республикасындағы тілдік ахуалды зерделеуде өңірлік тәсілдің қажеттігі туындайды. Атап айтсақ, көптілділік жағдайында шет тілін оқытудағы орыс тілінің рөлі мен орнын анықтау жеткіліксіз зерттелген. Орыс тілі ҚР-да қабылданған жалпы қарым-қатынастың әмбебап құралы ғана емес, сонымен қатар ғылымдарды танудың негізгі және шет тілін үйренуде тірек құрал болып табылады. Көптілділік жағдайында шет тілін оқытудың лингвоәдістемелік жағдайы көптілді аудиторияда шет тілін оқытудың лингвоәдістемелік жағдайынан көптеген параметрлері бойынша ерекшеленеді.

Кілт сөздер: көптілділік, лингвистикалық аспект, психологиялық аспект, тіл, шет тілі, тілдік жағдай, тілдерді өзара түсіну, тіл мәдениеті. 


\title{
А. Ким, Д. Асанова, М. Кноль \\ Сущность и содержание психолого-педагогической проблемы многоязычия: лингвистический и психологический аспекты
}

\begin{abstract}
В последнее время концепция многоязычия стала определяющей в подходе к проблеме изучения языков. Многоязычие возникает по мере расширения в культурном аспекте языкового опыта индивидуума от языка, употребляемого в семье, до языка, используемого в обществе, и далее до овладения языками других народов. Индивидуум не «хранит» эти языки и культуры обособленно друг от друга, а формирует коммуникативную компетенцию на основе всех знаний и всего языкового опыта, где языки взаимосвязаны и взаимодействуют. Одним из важнейших подходов как к билингвальному, так и многоязычному образованию является, по нашему мнению, изучение психолингвистических, нейролингвистических механизмов формирования билингвизма, многоязычия. Своеобразие языковой ситуации Республики Казахстан заключается в наличии двуязычия, которое обусловлено в стране, как естественный процесс в многонациональном государстве. Однако каждый регион страны имеет свою специфику в языковом отношении. В связи с этим возникает необходимость регионального подхода в изучении языковой ситуации в Республике Казахстан. Стоит отметить, что определение роли и места русского языка при обучении иностранному в условиях многоязычия является недостаточно изученным. Русский язык является не только универсальным средством общения общепринятым в РК, но и основным средством познания наук и опорой при изучении иностранного языка. Лингвометодическая ситуация обучения иностранному языку в условиях многоязычия по многим параметрам отличается от лингвометодической ситуации обучения иностранному языку в одноязычной аудитории.
\end{abstract}

Ключевые слова: многоязычие, лингвистический аспект, психологический аспект, язык, иностранный язык, языковая ситуация, взаимное понимание языков, многоязычие, языковая культура.

\section{References}

1 Deshiriev, Yu.D. (2006). Predislovie k sborniku «Problemy dvuiazychiia i mnohoiazychiia» [Preface to the collection Problems of Bilingualism and Multilingualism]. Moscow [in Russian].

2 Avrorin, V.A. (2018). Dvuiazychie $i$ shkola. Tezisy nauchnoi konferentsii, posviashchennoi probleme dvuiazychiia $i$ mnohoiazychiia [Bilingualism and the school. Abstracts of the scientific conference devoted to the problem of bilingualism and multilingualism]. Moscow [in Russian].

3 Beliaev, B.V. (2015). Primenenie printsipa soznatelnosti v obuchenii inostrannomu yazyku. V sbornike «Psikholoiia obucheniia inostrannomu yazyku» [Application of the principle of consciousness in teaching a foreign language. In the collection: psychology of teaching a foreign language]. Moscow [in Russian].

4 Bertagaev, T.A. (2008). Bilingvizm i ego raznovidnosti v sisteme upotrebleniia [Bilingualism and its varieties in the system of use]. Problemy dvuiazychiia i mnogoiazychiia - Problems of bilingualism and multilingualism, 86. Moscow [in Russian].

5 Avrorin, V.A. (2010). Dvuiazychie i shkola. Problemy dvuiazychiia i mnohoiazychiia [Bilingualism and the school. Problems of bilingualism and multilingualism]. Moscow: Nauka [in Russian].

6 Vereshchagin, E.M. (2016). Psikhologicheskaia i metodicheskaia kharakteristika dvuiazychiia (bilingvizma) [Pedagogical and psychological characteristics of bilingualism]. Moscow [in Russian].

7 Mirzoeva, L.Yu., \& Akhmetzhanova, Z.K. (2019). K voprosu ob interferentnykh oshibkakh kak elemente yazykovogo landshafta $\mathrm{v}$ usloviiakh subordinativnogo poliiazychiia [On the issue of interference errors as an element of the language landscape in the context of subordinative multilingualism]. Vestnik Tomskogo gosudastvennogo universiteta. Filologiia, No. 60, 45-65. DOI: $10.17233 / 19986645 / 60 / 4$ [in Russian].

8 Itskovich, V.A., \& Shvartskopf, V.S. (2017). Passivnoe dvuiazychie i kultura rodnoi rechi. Problemy dvuiazychiia $i$ mnogoiazychiia [Passive bilingualism and the culture of native speech. Problems of bilingualism and multilingualism]. Moscow [in Russian].

9 Shcherba, L.V. (2009). Izbrannye raboty po yazykoznaniiu i fonetike [Selected works on linguistics and phonetics]. (Vol. 1). Saint-Petersburg [in Russian].

10 Bagirokov Kh. Z. (2004). Bilingvalnoe obrazovanie: vyzov vremeni [Bilingual education: the challenge of time]. Russkii yazyk i literatura $v$ kazakhskoi shkole - Russian language and literature in the Kazakh school. Moscow [in Russian].

11 Rozentsveig, V.Iu. (2014). O yazykovykh kontaktakh kak stepeni dvuiazychiia [About language contacts as a degree of bilingualism]. Voposy yazykoznaniia - Questions of linguistics. Moscow [in Russian].

12 Blokh, M.Ya. (2017). Teoreticheskaia grammatika anhliiskogo yazyka [Theoretical grammar of the English language]. Moscow [in Russian].

13 Ter-Minasova, S.G. (2004). Yazyk i mezhkulturnaia kommunikatsiia [Language and intercultural communication]. Moscow [in Russian]. 